\title{
Low-Level Laser Effect on Peripheral Sciatic Regeneration Under the Systemic Inflammatory Condition of Periodontal Disease
}

\author{
Jéssica Aline Malanotte ${ }^{1}$, Lucinéia de Fátima Chasko Ribeiro ${ }^{2}$, Ana Luiza Peretti ${ }^{1}$, Camila Mayumi Martin \\ Kakihata ${ }^{1}$, Andrey Potulsky³ , Ana Tereza Bittencourt Guimarães ${ }^{2}$, Gladson Ricardo Flor Bertolini ${ }^{2}$, Patricia \\ Oehlmeyer Nassar², Carlos Augusto Nassar ${ }^{2 *}$
}

'Biosciences and Health, Western Paraná State University (UNIOESTE), Cascavel, Brazil ${ }^{2}$ Biosciences and Health, Western Paraná State University (UNIOESTE), Cascavel, Brazil

${ }^{3}$ Agroecology and Sustainable Rural Development, Federal University of Southern Border - UFFS, Laranjeiras do Sul, Brazil

\section{*Correspondence to Carlos Augusto Nassar, Department of Periodontology, School of Dentistry, Western Paraná State University, Rua Universitária, 2069, Jardim Universitário, Cascavel, Paraná, Postal Code 85819-110, Brazil. Number: +55 (45) 32203168 E-mail: canassar@yahoo.com \\ Published online January 18 2020}

\begin{abstract}
Introduction: Periodontal disease (PD) is an inflammatory condition, which leads to tooth loss and promotes a systemic inflammatory state that can aggravate the nerve degeneration. As laser therapy may stimulate regeneration, this study aimed to evaluate the effect of the low-level laser (LLL) on peripheral nerve regeneration under the systemic inflammatory condition of PD.

Methods: Thirry-two male rats were used, distributed in 4 groups: nerve injury (NIG); periodontal disease with nerve injury (PDNI); nerve injury and treatment (TNIG); periodontal disease with nerve injury and treatment (PDNIT). On the 7 th day of the experiment, the animals had ligatures placed around the lower first molars. On the 22nd day, they underwent peripheral nerve damage, and on the 25th day, the LLL treatment was initiated, performed for two weeks. The sciatic functional index (SFI) was evaluated with subsequent euthanasia of all the animals on the 37 th day of the experiment. The sciatic nerve was collected for morphological and oxidative stress analysis and the hemi jaws for radiographic analysis.

Results: Regarding the SFI, there was no difference among the groups in the first evaluation (EV) pre-injury; as for theEV2, after injury, all the groups presented a decrease in these values, which remained in post-treatment. For the morphology of the PDNI, nerve tissue presented larger diameter fibers, whereas, for NIT and PDNIT, fibers had smaller diameters with endoneurial organization. When it comes to the antioxidant system, there was an increase in protein concentration, higher superoxide activity, and decreased glutathione transferase activity in the treated groups. Catalase and cholinesterase did not differ between the groups, and lipoperoxidation (LPO) increased in the PD groups. For the mandible radiographic analysis, it was possible to verify the induction of PD. Conclusion: As for the used parameters, the low-level laser was not effective in increasing the nociceptive threshold, but it contributed to the regeneration of nerve fibers, although the inflammation was still present in the site. However, the treatment was effective in protecting cells against oxidative damage due to increased SOD and increased protein, although the decrease in GST demonstrates the inhibition of this stage of the antioxidant system.
\end{abstract}

Keywords: Low-level laser; Periodontitis; Inflammation; Sciatic nerve.

\section{Introduction}

Periodontal disease (PD) is a chronic inflammatory condition in the supporting structure of teeth, triggered by gram-negative bacteria from the subgingival flora. These micro-organisms produce several endotoxins that release an immune response from the host to produce inflammatory mediators, aiming at the destruction of the connective tissue and the alveolar bone besides promoting a post-inflammatory systemic state. ${ }^{1-3}$

Another common inflammatory condition happens when the peripheral nerve suffers injuries by compression, provoking a functional alteration due to sensory and motor changes. ${ }^{4}$ Thus, macrophages and Schwann cells work together to remove axon and myelin.,

Through the production of inflammatory local mediators, this inflammatory response increases, producing free radicals from the injured site; these oxidants can promote hyperalgesia for increasing the tissue damage to the injured area. ${ }^{4,7}$

To accelerate the peripheral nerve regeneration and consequently to improve the patient's quality of life, several techniques and treatments have been developed.

Please cite this article as follows: Malanotte JA, Ribeiro LFC, Peretti AL, Kakihata CMM, Potulsky A, Guimarães ATB, et al. Low-level laser effect on peripheral sciatic regeneration under the systemic inflammatory condition of periodontal disease. J Lasers Med Sci. 2020;11(1):5664. doi:10.15171/jlms.2020.10. 
Among them, one of the resources that have been used to promote a functional improvement is the low-level laser (LLL), ${ }^{8,9}$ as it acts on the fibroblastic proliferation and the Schwann cells, which secrete neurotrophic factor for the nerve regeneration under a painkiller effect, as well as the release of anti-inflammatory cytokines. ${ }^{10}$

Its anti-inflammatory effect happens through the decrease of interleukins 6 and 1, tumoral necrosis factor, prostaglandins, and metalloproteinases. 9 There are, however, no available papers on the effect of the LLL on the peripheral nerve regeneration under the presence of PD. Therefore, this study aimed to evaluate the effect of the LLL under the systemic inflammatory condition of the PD on the SFI parameters, morphology, and oxidative stress.

\section{Material and Methods}

The research was carried out at the Injury and Physical Therapy Resources Study Laboratory (LELRF) in partnership with the Structural and Functional Biology Laboratory of the Western State University of Parana (UNIOESTE).

\section{Sample Group}

For this experiment, 32 male Wistar rats were used. They were 8 weeks old with an average weight of $250 \mathrm{~g}$ from UNIOESTE's central vivarium. The animals remained at the sectorial vivarium of LELRF under the controlled conditions of temperature $\left(23 \pm 2^{\circ} \mathrm{C}\right)$ and light (lightdark cycle of 12 hours); they also received water and commercial rat food at all times. The animals were distributed randomly in 4 groups of 8 animals each as described below:

- $\quad$ Nerve Injury Group (NIG)-nerve injury on the 15th day of the experiment;

- Periodontal disease with nerve injury (PDNI)induced $\mathrm{PD}$ on the first day and nerve injury on the 15th day of the experiment;

- Treated nerve injury group (TNIG)-nerve injury on the 15th day and treated under the low potency laser after 18 days of the experiment;

- Periodontal disease with nerve injury and treatment (PDNIT) - induced PD on the first day, nerve injury on the 15th day, and treatment with a LLL from the 18th day of the experiment until the end (Figure 1). All animals were euthanized after the last day of the LLL treatment, that is, on the 30th day of the experiment. All procedures for unfolding this research are described in the following subsections.

Induction of Periodontal Disease Protocol After 7 days of acclimatization for all animals in the sectorial vivarium, the rats were anesthetized with ketamine $(100 \mathrm{mg} / \mathrm{kg})$ and xylazine $(50 \mathrm{mg} / \mathrm{kg})$ (Sespo Indústria e Comércio Ltda, São Paulo, Brazil) and placed on the appropriate operatory table, which allowed the maintenance of buccal opening and better access to the teeth on the posterior jaw region. With the support of a modified pinch and an explorer probe, cotton ligatures number 40 were placed around the lower right and left first molars. This ligature acted as a gingival irritant for 30 days, provoking the accumulation of bacterial plaque and consequently the development of the PD. ${ }^{11}$

\section{Compression Injury of the Sciatic Nerve Experimental Model}

On the 15th day of the experiment, before performing the surgical procedure of compression injury of the sciatic nerve, the animals were weighed and anesthetized. A trichotomy was carried on the posterior region of the left thigh, and then, with the support of the scalpel, an incision parallel to the fibers of the biceps femoral muscle was done to expose the sciatic nerve and consequently its compression with a hemostatic pinch for 30 seconds. The pressure of the pinch was the same in all animals; having the second rack's teeth as a reference, all of them were done by the same person. An epineural suture with a 6.0 nylon string was placed as a mark in the injured spot. ${ }^{12}$ Afterward, the animal's skin was sutured with a catgut 4.0 string.

\section{Treatment Protocol}

On the third day after the nerve injury, that is, on the18th day of the experiment, a protocol of treatment with the low-level infrared laser started. The wavelength was 830 $\mathrm{nm}\left(\right.$ Ibramed $\left.^{\circledR}\right)$, previously set to $30 \mathrm{~mW}$ power, $30 \mathrm{~J} / \mathrm{cm}^{2}$ fluency, $0.3 \mathrm{~cm}^{2}$ exit irradiation area, $0.1 \mathrm{~W} / \mathrm{cm}^{2}$ irradiance and $9 \mathrm{~J}$ energy density, with a total of 2 minutes of daily

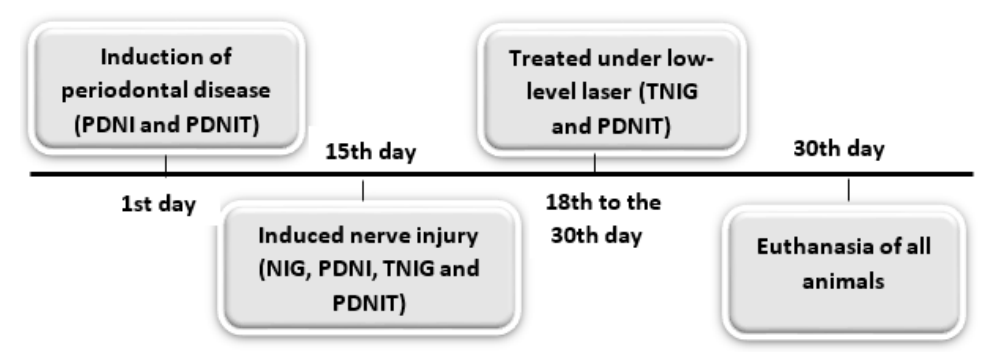

Figure 1. The period in which the experimental procedures were carried. NIG: Nerve injury group; PDNI: periodontal disease with nerve injury; TNIG: Treated nerve injury group; PDNIT: Periodontal disease with nerve injury and treatment. 
application. ${ }^{13}$ The therapeutical technique was direct and continuous; the equipment was placed perpendicularly to a single spot, specifically under the surgery incision. This procedure was repeated five days a week, with a break of 24 hours between the application, totalizing 2 weeks of treatment, with a break of 2 days between the first and second week, then coming down to 10 applications. The same person carried this treatment thoroughly on the TNIG and PDNIT groups.

Sciatic Functional Index

The animals were trained to walk on an acrylicbased treadmill for 5 days previous to the sciatic nerve compression. Each animal underwent 3 evaluations (EV) by a single researcher as follows: EV1 previous to the nerve compression; EV2 on the third day after the surgery of the nerve injury previous to the beginning of the treatment; and EV3 on the third day after accomplishing the treatment.

The SFI corresponds to the functional gait analysis based on the images from a recorded video, using a treadmill with controlled speed (Insight ${ }^{\circledR}$, Ribeirão Preto, São Paulo, Brazil). The recordings were done using a webcam, plugged through a USB cable directly connected to a portable computer. ${ }^{14}$

After recording, an image of each animal was selected and evaluated through the Image Pro-plus 6.0 (Media Cybernetics, Georgia, United States) program with variable measurements as suggested by Bain et al, ${ }^{15}$ print length (PL), the total spread of toes (TS) from the first to the fifth, and the total intermediate toes opening (IT) from the second to the fourth on the injured or experimental side (E) and the contralateral or normal side $(\mathrm{N})$. Once registered, the SFI value was calculated with the Microsoft ${ }^{\circledR}$ Excel 2016 for Windows through the formula: $\mathrm{IFC}=-38.3 \mathrm{x}[(\mathrm{EPL}-\mathrm{NPL}) / \mathrm{NPL}]+109.5 \mathrm{x}[(\mathrm{ETS}-$ NTS $) / N T S]+13.3 x[($ EIT-NIT $) / N I T]-8.8$

\section{Animal Euthanasia}

On the last day of the experiment (37th), all animals were weighed and anesthetized; dissection was done followed by the removal of $2 \mathrm{~cm}$ of the sciatic nerve, distal to the compression procedures for morphological and oxidative stress of the nerve tissue analysis. Soon after, the animals were euthanized by guillotine decapitation and their left hemimandibles were collected for posterior radiographic analysis.

\section{Morphologic Analysis}

The collected sciatic nerve fragments were fixated in paraformaldehyde $7 \%$ for 24 hours and then placed in alcohol $70 \%$, followed by the routine histological procedures for the inclusion in paraffin: dehydrated, diaphonized, infiltrated and put in the blocks of histological paraffin to obtain the transverse cuts of the nerve with a thickness of $5 \mu \mathrm{m} .{ }^{16}$ Subsequently, they were colored with hematoxylin and eosin for carrying out the descriptive analysis of the nerve tissue, the fiber integrality, and the presence of Schwann cells and inflammatory infiltration.

Biochemical Analysis

After collection, the sciatic nerve fragments were frozen, followed by the homogenization in $1 \mathrm{~mL}$ buffer Tris $\mathrm{HCl}$ $\mathrm{pH}$ 7.4. Then they were centrifuged to $12000 \mathrm{~g}$ for 10 minutes at $4^{\circ} \mathrm{C}$. The homogenate was frozen at $-20^{\circ} \mathrm{C}$ for later analysis.

The protein quantification in the samples was determined by the Bradford method, ${ }^{17}$ using the albumin of bovine serum as a pattern. All samples were normalized with $1 \mathrm{mg}$ of protein/mL.

\section{Enzyme Dosage Associated With Neurotoxicity}

The cholinesterase enzyme (ChE) activity analysis was performed through the methods developed by Ellman et al. ${ }^{18}$ Microplate adapted by Silva de Assis, ${ }^{19}$ in which the principle of measurement is the production of thiocholine when the acetylthiocholine (ATC) is hydrolyzed. The production is done by the continuous reaction of the thiol with the 5:5-dithiobis-2-nitrobenzoic acid, producing the anion of the yellow color of the 5-thio-2-nitrobenzoic acid.

The reaction was done in triplicate in $300 \mu \mathrm{L}$ of the solution with $0,05 \mathrm{mM}$ of acid, 5,5'-dithiobis-2nitrobenzóico (DTNB) and $1.5 \mathrm{mM}$ ATC. The activity of $\mathrm{ChE}$ was calculated about the protein concentration $(\mathrm{mg} / \mathrm{mL})$, using the coefficient of molar extinction of DTNB $\left(1.36 \mathrm{mM}^{-1} \cdot \mathrm{cm}^{-1}\right)$. The protein quantification was calculated by the gross sample and the reading was done to $22^{\circ} \mathrm{C}$. The results were expressed in $\mathrm{nmol} \cdot \mathrm{min}^{-1} \cdot \mathrm{mg}$ protein $^{-1}$.

Enzyme Dosage Associated With the Antioxidant System The activity of the superoxide dismutase (SOD) was evaluated according to a modification of the method proposed by Crouch et al. ${ }^{20}$ The principle of this analysis consists in quantifying the complex formed by the superoxide and the blue of tetrazolium (NBT), measured at $560 \mathrm{~nm}$ for 1.5 hours. An aliquot of $0.75 \mathrm{mg} / \mathrm{mL}$ protein in ethanol $25 \%$ was prepared in volume $800 \mu \mathrm{L}$ and centrifuged to $13680 \mathrm{~g}\left(4^{\circ} \mathrm{C}\right)$ for 20 minutes. From the supernatant, the reaction was prepared in a 96-well microplate. In triplicate, the final volume was added to 200 $\mathrm{uL}$, being $0.1 \mathrm{mg}$ de protein $\mathrm{mL}^{-1}, 0.09 \mathrm{mM}$ of NBT, 0.015 $\mathrm{mM}$ of EDTA, $34.78 \mathrm{mM}$ of sulfate of hydroxylamine, 79 $\mathrm{mM}$ of carbonate of sodium buffer $\mathrm{pH} 10.2$ and was stored at $22^{\circ} \mathrm{C}$. The unit of SOD in nmol.min ${ }^{-1}$.mg of protein ${ }^{-1}$.

The catalase activity (CAT) was followed by a decrease of 240 nmin absorption ${ }^{21}$ from the peroxide dismutation principle, for which the molar extinction coefficient is of $40 \mathrm{M}^{-1} \cdot \mathrm{cm}^{-1}$. The duplicates in $2 \mathrm{~mL}$ of solution in a quartz cuvette at $25^{\circ} \mathrm{C}$ presented a final concentration of $0.01 \mathrm{mg}$ of protein. $\mathrm{mL}^{-1}$ and the final concentration for 
the reaction medium of $13.5 \mathrm{mM}$ of $\mathrm{H} 2 \mathrm{O} 2,50 \mathrm{mM}$ of TRIS-HCl pH 8.0 and $0.25 \mathrm{mM}$ of EDTA. The results of the catalase enzyme were expressed in $\mathrm{mol}_{\mathrm{min}}{ }^{-1} \mathrm{mg}$ of protein $^{-1}$.

The principle of the glutathione transferase activity analysis (GST) is that the enzyme catalyzes the conjugation of reduced glutathione (GSH) with the synthetic CDNB substrate, which produces the conjugate detected in $340 \mathrm{~nm} .{ }^{22}$ During the trial, the enzymatic activity is proportional to the speed in the production of the conjugated compost. The experiment was performed in triplicate in a microplate so that the final concentration of the sample was $0.020 \mathrm{mg}$ of protein $\mathrm{mL}^{-1}$. The reaction medium presented final concentrations of $0.94 \mathrm{mM}$ of $\mathrm{CDNB}$ and $0.94 \mathrm{mM}$ of GSH, stored at $22^{\circ} \mathrm{C}$. The molar extraction coefficient conjugated GSH/CDNBis 9.6 $\mathrm{mM}^{-1} \cdot \mathrm{cm}^{-1}$ and the unit was expressed in nmol. $\mathrm{min}^{-1} \cdot \mathrm{mg}$ of protein $^{-1}$.

Non-enzymatic Reaction Associated With the Antioxidant System

Determining the lipoperoxidation (LPO) reaction was done to quantify the peroxide indirectly, thus reflecting the intensity of lipid peroxidation. ${ }^{23}$ The method of TBARS ${ }^{24}$ was done through the comparisons of absorption with curvature patterns of malondialdehyde (MDA), mainly the lipid peroxidation sub-product. For sample preparation, the medium with an aliquot of $0.33 \mathrm{mg} / \mathrm{mL}$ of protein in a sample of trichloroacetic acid (TCA) 6,7\% in a final volume of $180 \mu \mathrm{L}$ was agitated in a vortex, left in an ice bath for 5 minutes and centrifugated for 5 minutes to $12000 \mathrm{~g}$ at $4^{\circ} \mathrm{C}$. For the dose of reactive substances of thiobarbituric acid (TBARS), $40 \mu \mathrm{L}$ of supernatant, different from the concentration of MDA, was added to the microplate in triplicate, a reaction medium with 21.42 $\mathrm{mM}$ of TBA, $17.86 \mathrm{mM}$ of $\mathrm{NaOH}$ (used for solubilizing the TBA), $0.73 \mathrm{M}$ of TCA, $0.032 \mathrm{mM}$ de BHT, ethanol $3 \%$ (used for solubilizing the BHT) in PBS. At $22^{\circ} \mathrm{C}$, after 60 minutes of incubation, at $60^{\circ} \mathrm{C}$, in the absorption of $535 \mathrm{~nm}$. The peroxidation lipid results were expressed in mmol MDA.mg protein.

\section{Mandible Histomorphometric Analysis}

The right side hemimandibles were collected, dissected, and fixed in a solution of $10 \%$ formaldehyde. After that, the periapical radiographic film was put on the lingual side and placed so that the vestibular and lingual cusps of the first molars remained on the same vertical plane. The GE 1000 X-ray machine was used, set to $15 \mathrm{~mA}, 65 \mathrm{Vp}, 18$ impulses, focus/film distance $50 \mathrm{~cm}$ with $\mathrm{X}$-ray incidence perpendicular to the pieces. For the films, a Kodak ${ }^{\circledR}$ developer and a fixer solution were used, respecting the recommended time/temperature for film processing; then the films were scanned using a scanner for slides (Polaroid Sprint Scan 35 Plus, Polaroid). The digitalized images were analyzed by 3 steps using the Image Pro- plus 6.0 software (Media Cybernetics, Georgia, United States), and an average was drawn among them through a linear measurement, which covered the distance from the cementoenamel junction to the alveolar bone crest on the mesial side of the inferior mandibular first molar, measured in pixels. ${ }^{25}$

\section{Data Analysis}

The results were expressed and analyzed through descriptive and inferential statistical analysis. Firstly, they were evaluated by their normality according to the Shapiro-Wilk test and as they presented normal distribution, the ANOVA unidirectional test was used, followed by the Tukey test when there was a significant difference. The variable numbers were analyzed through the BioEstat 5.0 test. It was considered significant when $P<0.05 .{ }^{26}$ The variables of the radiographic mandibula analysis, protein, ChE, SOD, CAT, GST, and LPO were compared among the groups, and the normality of residues and the homogeneity of variances were verified by the Shapiro-Wilk test and the Levene test respectively. The variables were analyzed by the parametric test ANOVA - two way, followed by the LSD-Fisher test. The results were expressed by the average and pattern deviance.

\section{Results}

Sciatic Functional Index

In the first evaluation, there was no significant difference among the groups $(P=0.316)$; however, from the second evaluation on, after being submitted to the peripheric nerve injury, all groups showed a decrease in values $(P<0.05)$, not pointing at any improvement in the last evaluation after the treatment (Table 1).

\section{General Nerve Tissue Morphology}

The nerve tissue morphology in the nerve injury group (NIG) presented alterations with disorganized nerve fibers, making it impossible to visualize the axon and the endoneurial break. The extracellular medium revealed hypocellularity with an increase in the number of nuclei of Schwann cells, a high quantity of the inflammatory infiltrate, the presence of macrophages, and fibroblasts

\begin{tabular}{llll}
\multicolumn{4}{l}{ Table 1. Sciatic Functional Index } \\
\hline Groups & EV1 & EV2 & EV3 \\
\hline NIG & $-18.56 \pm 24.22 \mathrm{Aa}$ & $-75.58 \pm 14.23 \mathrm{Bb}$ & $-74.79 \pm 21.12 \mathrm{Bb}$ \\
PDNI & $10.84 \pm 27.77 \mathrm{Aa}$ & $-67.73 \pm 18.46 \mathrm{Bb}$ & $-72.62 \pm 23.71 \mathrm{Bb}$ \\
TNIG & $0.34 \pm 33.39 \mathrm{Aa}$ & $-74.83 \pm 16.00 \mathrm{Bb}$ & $-71.44 \pm 7.15 \mathrm{Bb}$ \\
PDNIT & $-4.59 \pm 26.13 \mathrm{Aa}$ & $-62.85 \pm 19.11 \mathrm{Bb}$ & $-67.78 \pm 17.01 \mathrm{Bb}$ \\
\hline
\end{tabular}

NIG, Nerve injury group; PDNI, periodontal disease with nerve injury; TNIG, nerve injury and treatment; PDNIT, periodontal disease with nerve injury and treatment; EV, Evaluation.

Note: Different letters indicate a statistically significant difference. Capital letters indicate differences among the columns (evaluations) and lower case letters the differences among the lines (groups). The values presented as mean \pm standard deviation. 
(Figure 2 NIG). No changes were verified on the perineural nerve, which kept its concentric layers with fibroblasts; the same occurred in the epineurial nerve with its collagen fibers with several orientations to support the elasticity of the tissue.

In the NIT group, it was possible to see a lower quantity of nuclei cells and the inflammatory infiltrate on the extracellular medium when compared to the NIG. Still, there was the presence of longer and shorter diameter nerve fibers and endoneurial reorganization (Figure 2 TNIG).

In the PDNIG, it was possible to verify the presence of integral nerve fibers mainly with longer diameters, average on the quantity of nuclei cells, Schwann cells, and the presence of swollen blood vessels besides the modulation of the endoneurial (Figure 2 PDNI)

In the PDNIT, it was possible to highlight the presence of a high quantity of integral nerve fibers of shorter diameter, the presence of hypercellularity when compared to the PDNIG, an increase in the Schwann cells and the inflammation infiltrate with the presence of macrophages showing that there was still an inflammation (Figure 2 PDNIT).

Antioxidant System Analysis

By evaluating the SOD, it was possible to observe that there was no significant statistic change in the disease factors and the laser application $(\mathrm{F}=0.435 ; P=0.546)$ as well as in terms of its isolated disease factor $(\mathrm{F}=2.099$; $P=0.221)$. However, the laser factor was considered statistically significant $(\mathrm{F}=14.517 ; \quad P=0.019)$ in the groups to which the procedure was applied, and the values of the SOD were higher $(\mathrm{PDNIG}=16.32 \pm 2.57 \mathrm{mg} /$ $\mathrm{mL} ; \mathrm{PDNIT}=14.53 \pm 1.66)($ Figure $3 \mathrm{~A})$.

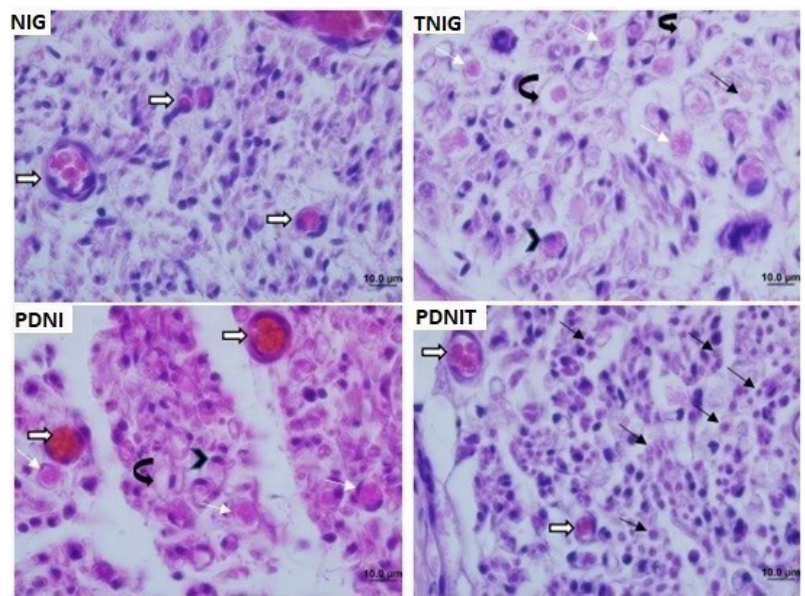

Figure 2. Transversal Cuts of Wistar Rats Sciatic Nerve Photomicrographs. Integral fibers with longer diameters (thin white arrow), integral fibers with shorter diameters (thin black arrow), Schwann cell (arrowhead), endoneurial (curved arrow), blood vessel (white arrow) (Hematoxylin and eosin). Abbreviations: NIG, Nerve injury group; PDNI, periodontal disease with nerve injury; TNIG, nerve injury and treatment; PDNIT, periodontal disease with nerve injury and treatment.
The evaluation of the CAT showed no significant statistic difference in the interaction between the disease factors and the laser application $(\mathrm{F}=3.94 ; P=0.062)$ as well as in relation with the isolated factors $(P>0.05)$, pointing at explicative variables that do not promote the effects upon the catalase enzyme variation (Figure 3B).

Regarding the GST evaluation, observation showed that there was no statistically significant difference in the interaction between the disease factor and the laser application $(\mathrm{F}=0.665 ; P=0.425)$ and also when it comes to the disease as a single isolated factor $(\mathrm{F}=0.534 ; P=0.474)$. However, the laser factor was considered statistically significant $(\mathrm{F}=6.321 ; P=0.021)$, meaning that for the groups in which the procedure was applied, the values of GST were lower than the others (NIT $=5.736 \pm 0.801 \mathrm{mg} /$ $\mathrm{mL} ; \mathrm{PDNIT}=5.983 \pm 0.906)($ Figure $3 \mathrm{C})$.

For the LPO evaluation, observation showed that there was no statistically significant difference in the interaction of the disease factor and the laser application $(\mathrm{F}=0.031 ; P=0.860)$, as only the laser application was also not statistically significant $(\mathrm{F}=0.452 ; P=0.506)$ (Figure 3D). However, the isolated disease factor was considered statistically significant $(\mathrm{F}=7.049 ; P=0.012)$ in the groups which presented significantly higher averages $(\mathrm{PDNIG}=0.019 \pm 0.008 ; \mathrm{PDNIT}=0.015 \pm 0.006)$ (Figure 3D).

\section{Biochemical Analysis}

By evaluating the protein concentration, there were no statistically significant interactions between the disease factors and the laser application $(\mathrm{F}=0.072 ; P=0.791)$ and also when it comes only to the disease isolated factor $(\mathrm{F}=1.06 ; P=0.313)$. However, this factor was considered statistically significant $(\mathrm{F}=5.73 ; P=0.024)$ in
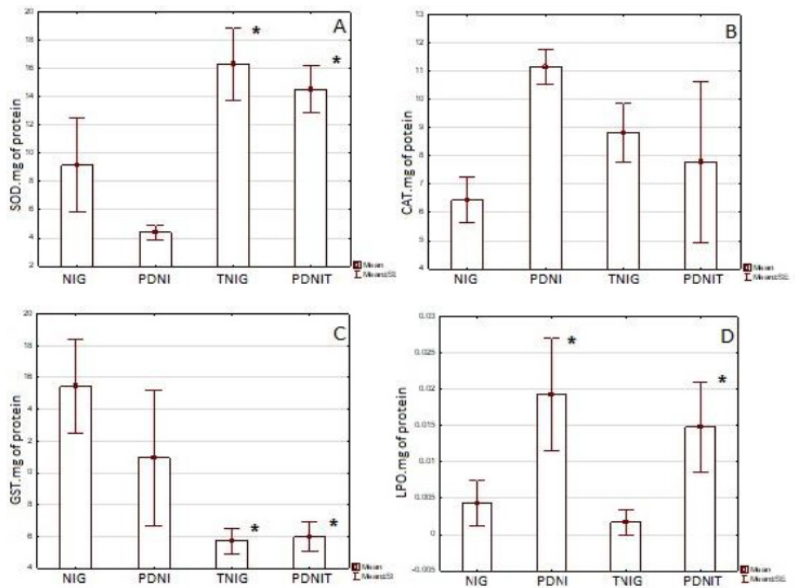

Figure 3. Biomarkers Activity of the Wistar Rats Sciatic Nerves. (A) Superoxide dismutase (SOD); (B) Catalase (CAT); (C) Glutathione transferase (GST); (D) Lipoperoxidation (LPO). Nerve injury group (NIG); Periodontal disease with injury group (PDNI); Nerve injury with treatment (NIT) and Periodontal disease with nerve injury and treatment (DPNIT). *Statistically significant difference. 

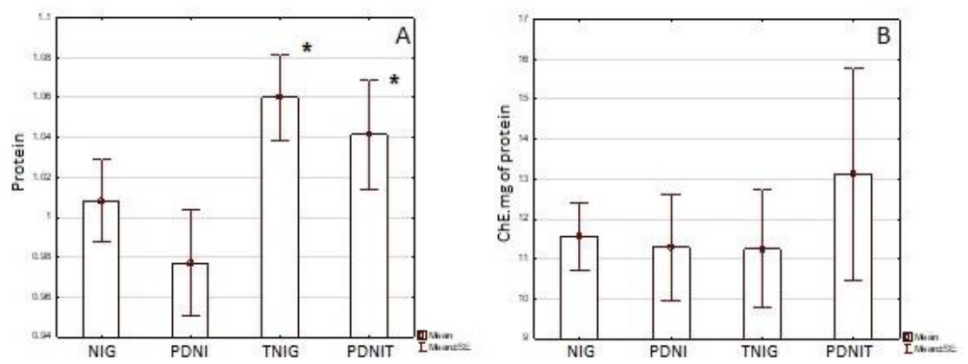

Figure 4. Biomarkers of Wistar Rats Sciatic Nerve. (A) Protein; (B) Cholinesterase (ChE). Abbreviations: NIG, Nerve injury group; PDNI, periodontal disease with nerve injury; TNIG, nerve injury and treatment; PDNIT, periodontal disease with nerve injury and treatment. * Statistically significant difference.

the groups to which the procedure was applied, and the values of protein were higher $(\mathrm{NIT}=1.06 \pm 0.02 \mathrm{mg} / \mathrm{mL}$; $\mathrm{PDNIT}=1.04 \pm 0.03$ ) (Figure 4A).

Regarding the cholinesterase, there was no significant difference in the interaction of the factors $(F=0.4$; $P=0.534)$ as well as with the separated factors $(P>0.05)$, indicating that those explicative variables did not promote the effects on the ChE variation (Figure 4B).

\section{Radiographic Analysis}

In the radiographic analysis, verification showed that there was a loss in the supportive teeth tissue absorption of those animals exposed to the experimental PD $(P<0.01)$, pointing at the effectivity of the PD induction in the alveolar bone tissue (Table 2).

\section{Discussion}

After the peripheric nerve injury, the individuals rarely presented a full functional recovery. Although the regeneration ability is higher compared to the central nerve system, in many of the cases, the motor and sensory reinnervation is misdirected or associated with debilitating neuropathic pain. It causes a problem for the central nervous system to interpret a new pattern of the signal from the periphery, a fact that could become a relevant obstacle to recovery and functional results. ${ }^{27}$

In this study, it was not possible to highlight a functional improvement through the IFC evaluation 15 days after LNP and treatment with laser. There was only a difference between the EV1 (pre-injury) and the other (post-injury) evaluations. EV2 and EV3 presented a lower nociceptive threshold, which means that there was no improvement

Table 2. Distance Average of the Cementoenamel Junction to the Alveolar Bone Crest on the Mesial Side of the Inferior Mandibular First Molar

\begin{tabular}{lc}
\hline Groups & Patterns \\
\hline NIG & $0.85 \pm 0.05 \mathrm{~A}$ \\
PDNI & $1.11 \pm 0.11 \mathrm{~B}$ \\
TNIG & $0.81 \pm 0.04 \mathrm{~A}$ \\
PDNIT & $1.11 \pm 0.05 \mathrm{~B}$ \\
\hline
\end{tabular}

Abbreviations: NIG, Nerve injury group; PDNI, periodontal disease with nerve injury; TNIG, nerve injury and treatment; PDNIT, periodontal disease with nerve injury and treatment. on those animals submitted to the DP and treated, while the DP seemed not to have played any influence on this parameter.

Similar results were found in the study by Karvat et al, ${ }^{28}$ in which, after the compression of the sciatic nerve, LLL treatment of $830 \mathrm{~nm} 4 \mathrm{~J} / \mathrm{cm}^{2}$, and neural mobilization, they could draw a significant difference between the EV1 (higher nociceptive threshold) and the others, concluding that the used protocol was not efficient to change the nociceptive threshold.

As for the study by Rosa-Junior et $\mathrm{al},{ }^{10}$ which associated the LNP treatment with laser, swimming, and laser associated with swimming, using the LLL $904 \mathrm{~nm} 40 \mathrm{~J} /$ $\mathrm{cm}^{2}, 8 \mathrm{~J} / \mathrm{cm}^{2}$ and $120 \mathrm{~J} / \mathrm{cm}^{2}$, the conclusion was that aligning of the treatment resources favored the functional recovery of these animals, pointing that the laser only was not capable of presenting a better result, and a complementary treatment was required.

In most of the cases, satisfactory results are mainly limited to the injury type, as neurapraxia and axonotmesis, classified as relatively mild injuries. ${ }^{29}$ Thus, the axonotmesis injury has the ideal conditions for new axon growth, as the intact endoneurial tube presence conduct to a better result for the peripheric nerve regeneration. ${ }^{30}$ This fact could be observed in this present study, on the TNIG and PDNIT, in which it was possible to highlight the presence of the formed endoneurial, providing support for the already present axon growth. While it was possible to observe that the regeneration was already happening in the PDNIT, there was still an inflammatory process on the site, showing that the PD accelerates, even in a small way, the peripheric nerve regeneration.

The results found by Gonçalves et $\mathrm{al}^{31}$ showed that therapy with laser application of $830 \mathrm{~nm}, 4 \mathrm{~J} / \mathrm{cm}^{2}$ for 14 days contributed to the decrease in the inflammatory process triggered by the compressing injury of the sciatic nerve. ${ }^{28}$ This is in accordance with the findings from this study, in a way that an improvement on the TNIG inflammatory process could be observed, as the laser acts as a regulator of the micro medium and provides a nerve regeneration in an effective way. ${ }^{32}$ Also, as observed in this study, the presence of integral fibers, presents mostly 
shorter diameters lengthin the treated groups.

Soon after the injury, the Schwann cells are responsible for the degradation of myelin phagocytosis, which is an increase in arriving macrophages at the site. This phase has its pick three days after the injury and could continue for 14 to 21 days. ${ }^{5}$ It could have happened with the NIG group, which was not submitted to the treatment and still presented an intense inflammatory process.

As the axons regenerate, the interactions of Schwannaxon cells are renewed. This renewal triggers the remyelination and the recovering of the physiologic function of the nerve fiber. Although the recovery and the remyelination are possible for the peripheric nerve system, the remodeled axons usually have thinner myelin sheaths and decrease on the internodal length, taking to a slow conduction of the nerve impulse ${ }^{27}$; this fact could be observed in the TNIG and PDNIT groups, which presented regenerated fibers, still with shorter diameters.

Moreover, the study of Svennigsen and Dahlin ${ }^{27}$ showed that the matrix metalloproteinases-9 (MMP-9), responsible for regulating the levels, the functionality of the matrix extracellular compounds, and the superficial cellular receptors signals, is involved in the myelination process as well as in the internodal length determination. This was reported on the fact that the remyelination nerve in the rats did not present MMP-9 and the Schwann cells were not capable of forming longer internodes, implicating that this protein is involved in generating the development and the regenerative Ranvier nodules generation. ${ }^{27}$ Thus, the PDNIT nerve fiber presented longer diameters, which could be related to the increase of MMP release caused by the DP, pointing at a possibility to restore the proper conduction of remyelinated fibers.

Although there was an increase in the nerve cells, it was not possible to identify changes in the cholinergic activity, measured in this study through an evaluation of the ChE activity. This enzyme has the function of ending the cholinergic neurotransmission by hydrolysis, cleaving acetylcholine into acetic acid and choline. It is found mainly in neuromuscular junctions and cholinergic synapsis, in which its activity serves to finish the synaptic transmission, being the nerve impulse transmission ${ }^{33}$ key enzyme.

The LLL treatment caused an increase in the concentration of proteins. This result is in accordance with the information found by Filipin et al, ${ }^{34}$ who investigated the LBO effects on the antioxidant system and the process of fibrosis and an experimental calcaneal tendon injury. In this study, the researchers mentioned that the application of LLL with a wavelength of $904 \mathrm{~nm}$ and a power of 5 $\mathrm{J} / \mathrm{cm}^{2}$ for 14 to 21 days increased the plasmatic protein concentration significantly.

The nerve injury causes many neurochemical adaptations, regulating the chemical compounds, involving reactive oxygen species (ROS) in this process. ${ }^{35}$ As the production of ROS is higher than the antioxidant activity in the system, an oxidative stress state is characterized and cell damage can occur. ${ }^{36}$

Regarding the antioxidant activity, the inflammatory response induced by the LNP provokes the migration of neutrinos and macrophages, which causes fast oxygen consumption. This mechanism activates the NADPHOxidases, catalyzing the transference of electrons of NADPH to oxygen, forming a superoxide, ${ }^{37}$ which could have occurred to TNIG and PDNIT for their presenting of higher concentration of SOD. In these groups, the inflammatory process was still present, as observed in the general tissue morphology, supposing that the treatment with $\mathrm{LBO}$ at $30 \mathrm{~J} / \mathrm{cm}^{2}$ promoted the formation of ROS, and consequently the result was the increase of enzymatic activity of SOD. Still, in a study by Silveira et $\mathrm{al},{ }^{37}$ the results showed a decrease in the enzymatic activity of SOD in mice treated with LLL for 5 days with a power of 2 and $4 \mathrm{~J} / \mathrm{cm}^{2}$ during the process of experimentally induced wound healing.

As to the CAT enzyme that catalyzes the decomposition of the hydrogen to oxygen and water, ${ }^{35}$ subsequent to the enzyme SOD activity of the antioxidant system, results suggested no interaction of the factors of the study (laser and PD), affecting these enzymes in the animals with an injury. When it comes to the enzymes of GSTs of the antioxidant system, they catalyzed many reactions, mainly involved in the detoxification of the endogenous and exogenous electrophiles compounds. These compounds can harm the body since they area combination of glutathione and the target molecules. ${ }^{38}$ This enzymatic complex presented reduced in TNIG and the PDNIT, indicating that the treatment promoted an antioxidant system inhibition. However, this could have occurred due to the radiation effect $\left(30 \mathrm{~J} / \mathrm{cm}^{2}\right)$, affecting other corporal systems, such as fluids $\mathrm{pH}$ and calcium transportation. ${ }^{39}$

Regarding the LPO, one of the primary lipid degradation markers had its increase in the groups PDNI and PDNIT, suggesting that the PD promoted the increase of this reaction, which could have happened due to the local and systemic inflammatory process. Bastos et $\mathrm{al}^{40}$ related the levels of LOP with the periodontal state and the inflammatory cytokines in diabetic and non-diabetic patients, verifying an essential association between this reaction and the severity of the $\mathrm{PD}$ bacteria inflammatory response, indicating a direct relation between the LPO levels, the inflammation severity, and inflammatory cytokines secretion. As for its turn, the study of Silveira et $\mathrm{al}^{37}$ pointed at the LLL irradiation with $2 \mathrm{~J} / \mathrm{cm}^{2}$ and $4 \mathrm{~J} /$ $\mathrm{cm}^{2}$ for five days, promoting an LPO reaction reduction. The DP treatment was not efficient to minimize the lipid damage.

Although the results showed considerable relevance, it is possible to highlight the necessity of more investigative studies due to the absence of studies related to the association of LNP with the PD in the literature. Moreover, the effects of laser and its pattern of use in terms of 
time, power, and session numbers are recommended for further research, thus contributing to the development of the therapeutical treatment in the peripheric nerve regeneration.

\section{Conclusion}

It is possible to conclude from the above-mentioned points that the LLL with a wavelength of $830 \mathrm{~nm}$ and fluency of $30 \mathrm{~J} / \mathrm{cm}^{2}$ contributed to the regeneration of nerve fibers, even though the inflammation could still be present at the site. Moreover, the treatment was adequate to protect the cells against the oxidative damage due to the increase of SOD and the increase of proteins; however, a decrease in the GST shows an antioxidative system inhibition in this stage.

\section{Ethical Considerations}

All experimental procedures were submitted and approved by the Ethical Committee of Animal Use of UNIOESTE (Ethical code 07/18 - number 46/16).

\section{Conflict of Interests}

The authors declare no conflict of interest.

\section{Acknowledgments}

We thank the post-graduation program of Bioscience and Health and the Western State University of Parana for the opportunity to carry this study out. We thank Capes for granting the scholarship and the Araucaria Foundation (Edital 09/2016 - Basic and Applied Research) for the financial support.

\section{References}

1. Ide M, Harris M, Stevens A, Sussams R, Hopkins V, Culliford D, et al. Periodontitis and Cognitive Decline in Alzheimer's Disease. PloS One. 2016;11(3):e0151081. doi: 10.1371/journal.pone.0151081.

2. Mootha A, Malaiappan S, Javakumar ND, Varghese SS, Toby Thomas J. The effect of periodontitis on expression of interleukin-21: a systematic review. Int J Inflam. 2016;2016:3507503 . doi: 10.1155/2016/3507503.

3. Cortés-Vieyra R, Rosales C, Uribe-Querol E. Neutrophil functions in periodontal homeostasis. I Immunol Res. 2016;2016:1396106. doi: 10.1155/2016/1396106.

4. Karvat J, Kakihata CM, Vieira L, Antunes JS, Ribeiro LDF, Bertolini GR. Evaluation of nociception and edema in experimental sciatic nerve compression model in Wistar rats treated with cryotherapy. Rev Dor. 2016;17(3):210-14. doi: 10.5935/1806-0013.20160073.

5. Bombeiro AL, Santini JC, Thomé R, Ferreira ER, Nunes $\mathrm{SL}$, Moreira BM, et al. Enhanced immune response in immunodeficient mice improves peripheral nerve regeneration following axotomy. Front Cell Neurosci. 2016;10151. doi: 10.3389/fncel.2016.00151.

6. Sta M, Cappaert NL, Ramekers D, Baas F, Wadman WJ. The functional and morphological characteristics of sciatic nerve degeneration and regeneration after crush injury in rats. J Neurosci Methods. 2014;222:189-98. doi: 10.1016/j. jneumeth.2013.11.012.

7. Guedes RP, Bosco LD, Teixeira CM, Araújo AS, Llesuy S, Béllo-Klein A, et al. Neuropathic pain modifies antioxidant activity in rat spinal cord. Neurochem Res. 2006;31(5):6039. doi: 10.1007/s11064-006-9058-2.

8. Antunes JS, Karvat J, Aragão FA, Bertolini GRF. Low Power Laser In The Red Light Spectrum In Peripheral Nervous Injury: Systematic Review [laser de baixa potência, no espectro de luz vermelha, em lesão nervosa periférica: revisão sistemática]. Revista Pesquisa em Fisioterapia. 2015;5(1):43-8. doi: 10.17267/2238-2704rpf.v5i1.489. [Portuguese].

9. de Souza MV, da Silva MO. Laser therapy in locomotor disorders: a systematic review of experimental studies [laserterapia em afecções locomotoras: revisão sistemática de estudos experimentais]. Rev Bras Med Esporte. 2016; 22(1):76-82. doi: 10.1590/1517-869220162201144326. [Portuguese].

10. Rosa-Junior GM, Magalhães RMG, Rosa VC, Bueno CRS, Simionato $\mathrm{LH}$, BortolucI $\mathrm{CH}$. Effect of the association of laser therapy with swimming in the morphological repair of the sciatic nerve and the functional recovery of rats submitted to axonotmosis[Efeito da associação da laserterapia com a natação no reparo morfológico do nervo isquiático e na recuperação funcional de ratos submetidos à axonotmese]. Fisioter Pesq . 2016;23(1):12-20. [Portuguese]. doi: 10.1590/1809-2950/13929623012016.

11. Nassar PO, Nassar CA, Guimarães MR, Aquino SG, Andia DC, Muscara MN, et al. Simvastatin therapy in cyclosporine A-induced alveolar bone loss in rats. J Periodontal Res. 2009;44(4):479-88. doi: 10.1111/j.1600-0765.2008.01143.x.

12. Bridge PM, Ball DJ, Mackinnon SE, Nakao Y, Brandt K, Hunter DA, et al. Nerve crush injuries-A model for axonotmesis. Exp Neurol. 1994;127(2):284-90. doi:10.1006/ exnr.1994.1104.

13. Andreo L, Soldera CB, Ribeiro BG, de Matos PRV, Bussadori SK, Fernandes KPS, et al. Effects of photobiomodulation on experimental models of peripheral nerve injury. Lasers Med Sci. 2017;32(9):2155-2165. doi: 10.1007/s10103-0172359-7.

14. Monte-Raso VV, Fonseca MDC, Mazzer N, Barbieri G, Rosa RC, Zamarioli A, et al. Treadmill with controlled speed for recording gait. Acta Ortop Bras. 2010;18(1): 4953. doi: 10.1590/S1413-78522010000100010.

15. Bain JR, Mackinnon SE, Hunter DA. Functional evaluation of complete sciatic, peroneal, and posterior tibial nerve lesions in the rat. Plast Reconstr Surg. 1989;83(1):129-38. doi: 10.1097/00006534-198901000-00024.

16. Junqueira LC, Junqueira LMMS. Basic Techniques of Cytology and Histology [Técnicas básicas de citologia e histologia]. São Paulo: Guanabara Koogan; 1983. [Portuguese]

17. Bradford MM. A rapid and sensitive method for the quantitation of microgram quantities of protein utilizing the principle of protein-dye binding. Anal Biochem. 1976;72(1-2):248-54. doi: 10.1016/0003-2697(76)90527-3.

18. Ellman GL, Courtney KD, Andres V Jr, Feather-Stone RM. A new and rapid colorimetric determination of acetylcholinesterase activity. Biochem Pharmacol. 1961;7(2):88-95. doi: 10.1016/0006-2952(61)90145-9.

19. Silva de Assis HC. The use of biomarkers for the summary 
recording of water pollution [Der einsatz von biomarkern zur summarischen erfassung vom Gewässerverschmutzungen]. [Ph.D. thesis]. Berlin: University of Berlin; 1998. [German]

20. Crouch RK, Gandy SE, Kimsey G, Galbraith RA, Galbraith GM, Buse MG. The inhibition of islet superoxide dismutase by diabetogenic drugs. Diabetes. 1981;30(3): 235-41. doi: 10.2337/diab.30.3.235.

21. Aebi H. Catalase in vitro. Methods Enzymol. 1984;105:1216. doi: 10.1016/s0076-6879(84)05016-3.

22. Habig WH, Pabst MJ, Jakoby WB. Glutathione S-transferase AA from rat liver. Arch Biochem Biophys. 1976;175(2):7106. doi: 10.1016/0003-9861(76)90563-4.

23. Lushchak OV, Kubrak OI, Storey JM, Storey KB, Lushchak VI. Low toxic herbicide Roundup induces mild oxidative stress in goldfish tissues. Chemosphere. 2009;76(7):932-7. doi: 10.1016/j.chemosphere.2009.04.045.

24. Buege JA, Aust SD. Microsomal lipid peroxidation. methods Enzymol.1978;52:302-10. doi: 10.1016/s00766879(78)52032-6.

25. Nassar CA, Nassar PO, Inagaki NS, Girelli-Junior C. The effect of anti-inflammatory effect in the development of induced periodontal disease. Radiographic evaluation in rats [Efeito de Antiinflamatório no Desenvolvimento da Doença Periodontal Induzida. Avaliação Radiográfica em Ratos]. Revista de Odontologia da UNESP. 2003;32(2): 125130. [Portuguese].

26. Field A. Discovering Statistics Using SPSS (Introducing Statistical Methods series). 3rd ed. Sage publication; 2009.

27. Svennigsen AF, Dahlin LB. Repair of the peripheral nerve remyelination that Works. Brain Sci. 2013;3(3):1182-1197. doi: 10.3390/brainsci3031182.

28. Karvat J, Antunes JS, Bernardino GR, Kakihata CMM, Bertolini GRF. Effect of low-level laser and neural mobilization on nociceptive threshold in experimental sciatica. Rev Dor. 2014;15(3):207-10. doi: 10.5935/18060013.20140045.

29. Houschyar KS, Momeni A, Pyles MN, Cha JY, Maan $\mathrm{ZN}$, Duscher D, et al. The Role of current techniques and concepts in peripheral nerve repair. Plast Surg Int. 2016;2016: 175293. doi: 10.1155/2016/4175293.

30. Menorca RMG, Fussel TS, Elfar JC. Peripheral nerve trauma: mechanisms of injury and recovery. Hand Clin. 2013;29(3):317-30. doi: 10.1016/j.hcl.2013.04.002.

31. Gonçalves RB, Marques JC, Monte-Raso VV, Zamarioli A, Carvalho LC, Fazan VPS, Tavares MR. Effects of the low power laser application on the regeneration of the sciatic nerve of rats [Efeitos da aplicação do laser de baixa potência na regeneração do nervo isquiático de ratos]. Fisioterapia e Pesquisa. 2010;17(1):34-39. doi:10.1590/ S1809-29502010000100007. [Portuguese].

32. Stratton JA, Shah PT. Macrophage polarization in nerve injury: do Schwann cells play a role? Neural Regen Res. 2016;11(1):53-7. doi: 10.4103/1673-5374.175042.

33. Gupta VK, Kumar A, Siddiqi NJ, Sharma B. Rat brain acetyl cholinesterase as a biomarker of cadmium-induced neurotoxicity. J Tox. 2016; 1(1): 001-007. doi: 10.19080/ OAJT.2016.01.555553

34. Fillipin LI, Mauriz JL,vedovelli k, Moreira AJ, Zettler $\mathrm{CG}$, Lech $\mathrm{O}$, et al. Low-Level laser therapy (lllt) prevents oxidative stress and Reduces Fibrosis in Rat traumatized Achilles Tendon. Lasers Surg Med. 2005;37(4):293-300. doi: 10.1002/lsm.20225.

35. Guedes RP, Dal Bosco L, Araújo AS, Béllo-Klein A,Ribeiro MF, Partata WA. Sciatic nerve transection increases glutathione antioxidant system activity and neuronal nitric oxide synthase expression in the spinal cord. Brain Res Bull. 2009;80(6):422-7. doi: 10.1016/j.brainresbull.2009.08.007.

36. Guaraldo SA, Serra AJ, Amadio EM, Antônio EL, Silva F, Portes LA, et al. The effect of low-level laser therapy on oxidative stress and functional fitness in aged rats subjected to swimming: an aerobic exercise. Lasers Med Sci. 2016;31(5):833-40. doi: 10.1007/s10103-016-1882-2.

37. Silveira PCL, Silva LA, Tuon T, Freitas TP, Streck EL, Pinho RA. Effects of low-level laser therapy on epidermal oxidative response induced by wound healing. Rev Bras Fisioter. 2009;13(4):281-7. doi: 10.1590/S141335552009005000040.

38. Ashor AW, Siervo M, Mathers JC. Vitamin C, Antioxidant Status, and Cardiovascular Aging. In: Malavolta M, Eugenio Mocchegiani E, eds. Molecular Basis of Nutrition and Aging. San Diego, United States: Elsevier; 2016. p. 60919. doi: 10.1016/B978-0-12-801816-3.00043-1

39. Bavrina AP, Monich VA, Malinovskaya SL. Photomodification of glutathione S-transferase activity by low-intensity light against Various Stress Factors. Biophysics. 2017;62(5):705-7. doi: 10.1134/S0006350917050037.

40. Bastos AS, Graves DT, Loureiro AP, Rosa Júnior C, Abdalla DS, Faulin Tdo E, et al. Lipid peroxidation is associated with the severity of periodontal disease and local inflammatory markers in patients with type 2 diabetes. J Clin Endocrinol Metab. 2012;97(8):E1353-62. doi: 10.1210/jc.2011-3397. 